\title{
LC, LC-MS/MS Studies for the Identification and Characterization of Degradation Products of Hydrochlorothiazide and Establishment of Mechanistic Approach towards Degradation
}

\author{
Anand Avinash Mahajan, ${ }^{a}$ Anil Keshavlal Thaker ${ }^{a}$ and Krishnapriya Mohanraj ${ }^{*, b}$ \\ ${ }^{a}$ School of Pharmacy \& Technology Management, SVKMs NMIMS, \\ V. L. Mehta road, 400056 Vile-Parle (W), Mumbai, India \\ ${ }^{b}$ Bombay College of Pharmacy, 400098 Kalina, Santacruz (E), Mumbai, India
}

\begin{abstract}
O objetivo do presente estudo foi separar, identificar e caracterizar os produtos de degradação de hidroclorotiazida, sob confições de estresse hidrolítico, oxidativo, fotolítico e térmico, conforme a diretriz Q1A (R2) da Conferência Internacional de Harmonização (ICH). A droga sofreu degradação sob estresse ácido, básico, neutro e oxidativo, enquanto permaneceu estável nas condições de estresse fotolítico e térmico. Dois produtos de degradação foram formados, os quais foram separados através de CLAE em coluna C18, usando um programa de eluição isocrática. Uma rota completa de fragmentação da droga foi estabelecida, primeiramente, com a ajuda de estudos de CL-EM/ EM. As amostras estressadas foram submetidas a estudos de CL-EM. Os dados dos espectros de massas foram empregados para caracterizar os produtos de degradação e atribuir estruturas. Os produtos de degradação foram identificados como 4-amino-6-cloro-1,3-benzenodissulfonamida e 6-cloro-2-oxi-3,4-diidro-2H-1,2,4-benzotiadiazina-7-sulfonamida-1,1-dióxido.
\end{abstract}

The objective of the present investigation was to separate, identify and characterize the degradation products of hydrochlorothiazide under hydrolytic, oxidative, photolytic and thermal stress conditions as per the International Conference on Harmonization (ICH) guideline Q1A (R2). The drug degraded under acidic, basic, neutral and oxidative stress, while it was stable under photolytic and thermal stress conditions. Two degradation products were formed, which were separated by using HPLC on C18 column using isocratic elution program. A complete mass fragmentation pathway of the drug was first established with the help of LC-MS/MS studies. The stressed samples were subjected to LC-MS studies. The obtained mass spectral data were employed to characterize the degradation products and assign structures. The degradation products were identified as 4-amino-6-chloro-1,3-benzenedisulfonamide and 6-chloro-2-oxy-3,4-dihydro-2H1,2,4-benzothiadiazine-7-sulfonamide 1,1-dioxide.

Keywords: stress studies, hydrochlorothiazide, LC-MS/MS, degradation pathway

\section{Introduction}

The stability indicating assay method can be specific or selective. Specific stability indicating assay method (SIAM) is developed to measure active ingredient in presence of all degradation products, excipients and additives expected to be present in the formulation. Selective stability indicating method is developed to measure active ingredients as well as degradation products in presence of excipients and additives. ${ }^{1}$ Regulatory ICH guidelines Q1AR2, Q3BR2, Q6A and FDA 21 CFR section 211 explicitly indicate the need

*e-mail: krishnapriyamohanraj@gmail.com of stress testing, identification of degradation products and development of validated stability indicating assay method. ${ }^{2-5}$ However these guidelines do not provide any specific practical methodology for stress testing. ${ }^{6}$ Hence degradation conditions, concentration of agent responsible for degradation and time of degradation, are to be determined empirically to achieve 15-20\% degradation of active ingredient.

Hydrochlorothiazide (HCTZ), chemically known as 6-chloro-3,4-dihydro-2H-1,2,4-benzothiadiazine-7sulphonamide 1,1-dioxide is a widely used thiazide diuretic (Figure 1).

It increases urinary excretion of sodium and water by inhibiting sodium reabsorption in the renal tubules. ${ }^{7,8}$ It is 
<smiles>NS(=O)(=O)c1cc2c(cc1Cl)NCNS2(=O)=O</smiles>

Figure 1. Structure of hydrochlorothiazide (HCTZ), 6-chloro-3,4-dihydro2H-1,2,4-benzothiadiazine-7-sulphonamide 1,1-dioxide

also used to treat hypertension and edema associated with congestive heart failure and renal and hepatic disorders. Monographs on HCTZ are included in US pharmacopeia (USP), European pharmacopoeia (EP) as a single drug as well as in combination with other drugs. ${ }^{9,10}$ These pharmacopoeias also mention three process impurities of HCTZ; one is chlorothiazide (CTZ) and other two are 4-amino-6-chlorobenzene-1,3-disulphonamide (ACD) and dimeric $\mathrm{HCTZ}-\mathrm{CH}_{2}-\mathrm{HCTZ}$.

Various spectrophotometric and high performance liquid chromatographic (HPLC) methods have been reported for quantitative determination of HCTZ in standalone and combination products. ${ }^{11-14}$ The literature also shows there are individual methods reported to study hydrolysis of hydrochlorothiazide and photolytic decomposition of hydrochlorothiazide in solution. ${ }^{15,16}$ Few stability indicating assay methods were reported for hydrochlorothiazide and hydrochlorothiazide combination products. ${ }^{17-21}$ Though these methods already exist in the literature, none of the methods carried out LC-MS/MS studies to characterize degradants and predict mechanistic approaches towards degradation by systematic stress study. Hence an attempt was made towards development of LC-MS/MS compatible stability indicating assay method that can quantify HCTZ in the presence of degradation products. Detailed mass fragmentation pathway and hydrolytic mechanism for HCTZ has been proposed from the LC-MS/MS data.

\section{Experimental}

\section{Chemicals and reagents}

HCTZ was obtained as gift sample from IPCA laboratories (Ratlam district, M.P., India) and was used without further purification. Analytical reagent (AR) grade sodium hydroxide $(\mathrm{NaOH})$ was purchased from Qualigens Fine Chemicals (Mumbai, India), hydrochloric acid ( $\mathrm{HCl})$ from Qualigens Fine Chemicals (Mahape, India), formic acid from S. D. Fine-Chem Ltd. (Mumbai, India) and hydrogen peroxide $\left(\mathrm{H}_{2} \mathrm{O}_{2}\right)$ from S. D. Fine-Chem Ltd. (Mumbai, India). HPLC grade acetonitrile (ACN) was purchased from S. D. Fine-Chem Ltd. (Mumbai, India). HPLC grade double distilled water was produced using quartz double distillation assembly from Lab-Sil Instruments (Bangalore, India)

Apparatus and equipment

Degradation studies were carried out on water bath (Meta-Lab, Mumbai) equipped with thermostat for temperature control. A hot air oven (Scientico, Mumbai) was used to carry out solid state thermal stress studies. Photostability studies were carried out in photostability chamber (Thermolab Scientific Equipments Pvt. Ltd., India). The photostability chamber consists of two ultraviolet (UV) and four white fluorescent lamps; both of these lamps were kept on during the photostability study. Calibrated lux and UV meters were used to measure visible illumination and near UV energy respectively. The data was recorded and processed using Stability V7.2T software on Dell computer.

High performance liquid chromatography (HPLC) system used consisted of Perkin Elmer series 200 quaternary pump, series 200 autosampler fitted with $20 \mathrm{~mL}$ injection loop and series 200 EP diode array detector (DAD). The output signal was monitored and processed using Total Chrome Workstation software on Dell computer.

LC-MS/MS studies were carried out on system in which LC part consisted of HPLC (UFLC XR Shimadzu, Japan). The MS system (API 4000, Applied Biosystems, and MDS SCIEX) consisted of quadrupole spectrometer. The data was processed and monitored using Analyst 1.5 software. The mass spectrometer was run in positive as well as negative ionization mode using electrospray ionization (ESI) with mass to charge $(\mathrm{m} / \mathrm{z})$ ratio in the range of $\mathrm{m} / \mathrm{z}, 60-1000$.

The separations were carried out on Inertsil ODS 3 $(250 \mathrm{~mm} \times 4.6 \mathrm{~mm}$, particle size $5 \mu \mathrm{m})$ column as stationary phase and acetonitrile (ACN): water (pH adjusted to 3.2 with formic acid) in the ratio $(15: 85, \mathrm{v} / \mathrm{v})$ as mobile phase. Isocratic elution system was employed with the flow rate of $1.0 \mathrm{~mL} \mathrm{~min}{ }^{-1}$. The mobile phase was used for diluting the samples.

The $\mathrm{pH}$ of mobile phase and other solutions was adjusted by using $\mathrm{pH}$ meter (Controlled Dynamics, India). Other equipments used were sonicator (Spectralab UCB 30) and analytical balance (Precissa XR 205 SMDR).

\section{Stress studies}

Stress studies were carried out according to ICH guidelines Q1A (R2). The drug was subjected to different stress conditions like hydrolysis, oxidation, dry heat and photolysis. The stress conditions were optimized to degrade at least $15-20 \%$ of the HCTZ. The analysis was carried out by HPLC with DAD. LC-MS system was used for 
characterization of degradants generated during different stress condition.

Hydrolytic decomposition of HCTZ was carried out separately under acidic, alkaline and neutral condition by heating $1 \mathrm{~mL}$ each of $\mathrm{HCl}\left(1 \mathrm{~mol} \mathrm{~L}^{-1}\right), \mathrm{NaOH}\left(1 \mathrm{~mol} \mathrm{~L}^{-1}\right)$ and water with $1 \mathrm{~mL}$ of $1000 \mu \mathrm{g} \mathrm{mL} \mathrm{m}^{-1} \mathrm{drug}$ at $80^{\circ} \mathrm{C}$ for different time intervals. Samples were neutralized after required exposure. Samples treated with acid were neutralized by using equal strength of base and vice-versa. HCTZ solution, $1 \mathrm{~mL}$ of $1000 \mu \mathrm{g} \mathrm{mL}^{-1}$ was heated with $1 \mathrm{~mL}$ of $3 \%$ and $6 \% \mathrm{H}_{2} \mathrm{O}_{2}$ at $80{ }^{\circ} \mathrm{C}$ for different time intervals for oxidative stress. Thermal and photo degradation was carried out on solid drug. In case of thermal degradation, the solid drug was heated in oven within sealed glass ampoule at $70{ }^{\circ} \mathrm{C}$ for a period of three days. In the same way, a control sample was maintained at room temperature. The drug was exposed to 1.25 million lux hours of fluorescent light and $200 \mathrm{Whm}^{-2}$ of UV light along with control sample, which was covered with aluminum foil for photodegradation. After required exposure under different stress conditions, the samples were diluted with the help of mobile phase to a predetermined concentration of original drug $\left(100 \mu \mathrm{g} \mathrm{mL}^{-1}\right)$ and injected in HPLC for analysis.

\section{Preparation of samples for HPLC analysis}

The samples were diluted up to $10 \mathrm{~mL}$ with mobile phase in case of acid, neutral, base and oxidative stress to produce a predetermined concentration of $100 \mu \mathrm{g} \mathrm{mL}^{-1}$ of hydrochlorothiazide (original drug concentration). The solid samples which were exposed for photo and thermal stress were also weighed appropriately and diluted with suitable quantity of mobile phase to produce $100 \mu \mathrm{g} \mathrm{mL}^{-1}$ of original drug

\section{Development of stability indicating method}

Literature survey revealed that most of the reported HPLC methods, including methods of official monographs for HCTZ, were developed on C18 column. In most of the reported methods, the mobile phase used generally consisted of acetonitrile as organic phase in combinations with different buffers as aqueous phase. Here, the objective was to develop a LC-MS/MS compatible method which does not permit use of nonvolatile buffers. So, initial trials were conducted using acetonitrile and water on C18 column to obtain good peak shape of HCTZ.

Initially HPLC analysis was performed on the different stress samples individually and later on mixture of all stress samples. Different modifications like optimization of $\mathrm{pH}$ using formic acid and variations in mobile phase ratios were tried out to obtain better resolution among the degradants and between HCTZ and degradants. A UV spectrum was recorded for $\mathrm{HCTZ}$ and degradants generated under stress condition with the help of DAD. All recorded spectra showed $225 \mathrm{~nm}$ as wavelength maximum; so $225 \mathrm{~nm}$ wavelength was selected for spectrophotometric determination. Best results were obtained with isocratic elution, acetonitrile: water, $\mathrm{pH}$ adjusted to 3.2 with the help of formic acid in the ratio of $15: 85 \mathrm{v} / \mathrm{v}$, at flow rate of $1.0 \mathrm{~mL} \mathrm{~min}^{-1}$. All components eluted within 15 min with good system suitability characteristics.

\section{Validation of developed method}

The developed method was validated as per ICH guideline Q2 (R1). ${ }^{22}$ The linearity test solutions for HCTZ assay were prepared from stock solution (100 mg dissolved in $100 \mathrm{~mL}$ methanol) at five concentration levels from 10 to $80 \mu \mathrm{g} \mathrm{mL} \mathrm{m}^{-1}$. The solutions were injected in triplicate. The peak area versus concentration data was processed by least-square linear regression analysis. The correlation coefficient of calibration curve was calculated. The accuracy of the method was determined by standard addition. It was carried out by spiking mixtures of stressed samples containing $20 \mu \mathrm{g} \mathrm{mL}^{-1}$ of remaining HCTZ with three known concentrations of drug, viz., 20, 40, $60 \mu \mathrm{g} \mathrm{mL}^{-1}$ in triplicate and then determining percent recovery of the added drug. The intra-day and inter-day precision was carried out by analyzing 20, 40, $60 \mu \mathrm{g} \mathrm{mL}^{-1}$ drug solutions prepared in triplicate on the same day and on consecutive day. The specificity of the method was established by measuring peak purity and resolution for all the degradants and for HCTZ, which showed that the developed method was selective.

\section{Characterization of degradants}

The characterization of degradants was carried out by LC-MS/MS. Developed method was used as such, due to its compatibility with LC-MS/MS analysis. The obtained $\mathrm{m} / \mathrm{z}$, values in positive as well as negative ESI mode were used to predict structures of degradants and degradation pathways. The proposed structures and molecular weights of degradants were compared with known impurities listed in HCTZ drug monograph given in USP and EP.

\section{Results and Discussion}

HPLC studies on stressed solution

HCTZ on acid, alkaline and aqueous hydrolysis degrades to only one degradant (Deg. A). HCTZ on oxidative degradation produced two degradants, out of 


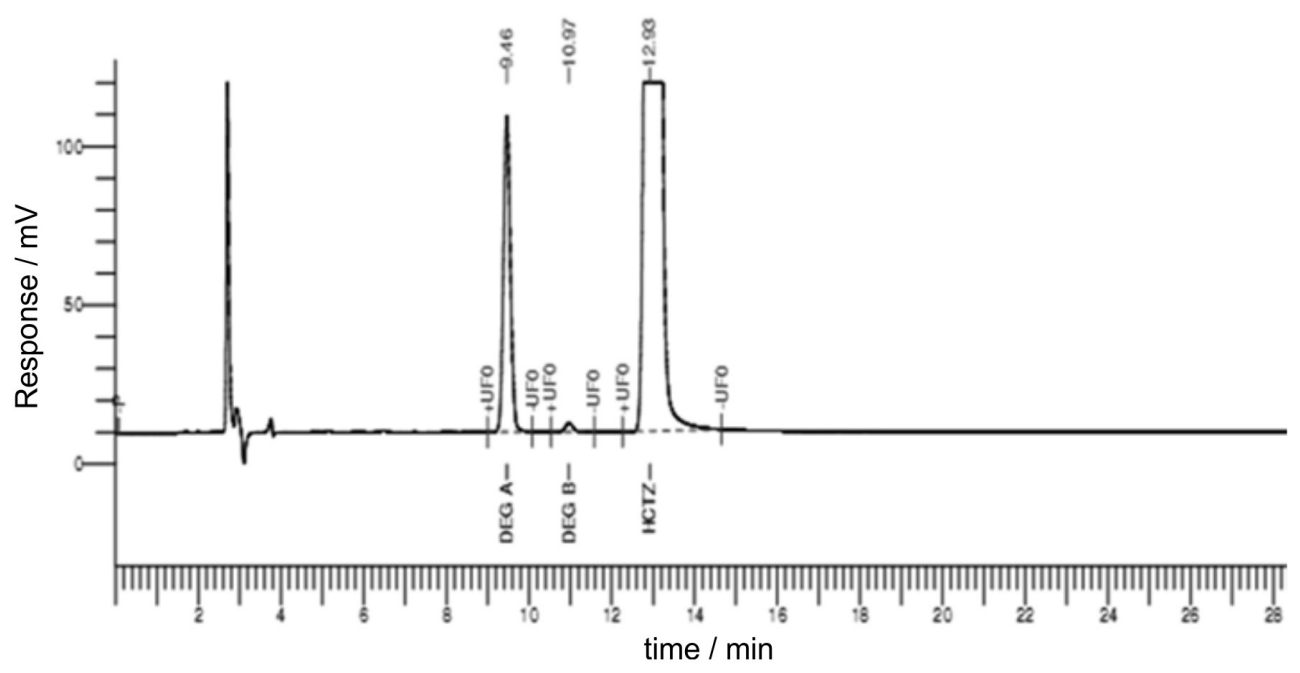

Figure 2. Chromatogram showing separation of HCTZ and its two degradation products (Deg. A and Deg. B).

which one of the degradants was found to be the same as that of the degradant generated during acid, neutral and base degradation, as it emerged at the same relative retention time $(\mathrm{RRT})$ as Deg. A $(\mathrm{RRT}=0.73)$, while the other degradant was different (Deg. B, RRT $=0.85$ ), as it emerged at a different RRT. RRT for both the degradants were calculated with reference to drug peak (HCTZ). It was further confirmed with DAD and LC-MS/MS analysis. The degradation products carry the notations Deg. A and Deg. B in accordance with the sequence in which the peak appears from left to right on the HPLC chromatogram (Figure 2).

\section{Hydrolytic degradation}

The drug showed degradation of $15 \%$ in $1 \mathrm{~mol} \mathrm{~L}^{-1} \mathrm{HCl}$ and $1 \mathrm{~mol} \mathrm{~L}^{-1} \mathrm{NaOH}$ at $80{ }^{\circ} \mathrm{C}$ over a period of half and $1 \mathrm{~h}$, respectively. It showed $22 \%$ degradation in neutral condition at $80^{\circ} \mathrm{C}$ in $2 \mathrm{~h}$. During all the above mentioned stress conditions only one degradant was formed at RRT of 0.73, which was denoted as Deg. A on HPLC chromatogram.

\section{Oxidative degradation}

In milder conditions $\left(3 \% \mathrm{H}_{2} \mathrm{O}_{2}\right.$, at $80{ }^{\circ} \mathrm{C}$ for $\left.1 \mathrm{~h}\right)$ oxidative degradation generated only one degradant, but when $\mathrm{HCTZ}$ was heated at $80^{\circ} \mathrm{C}$ with $6 \% \mathrm{H}_{2} \mathrm{O}_{2}$ for $2 \mathrm{~h}$, two degradants were formed. One of the degradants was found to be same as the degradant produced during hydrolytic degradation (Deg. A, RRT = 0.73) and another degradant eluted at RRT of 0.85 and it was denoted as Deg. B on HPLC chromatogram (Figure 2). In milder condition only Deg. B was observed, while in stronger condition Deg. A was also formed due to hydrolysis.
Photolytic degradation

No significant degradation was observed when solid HCTZ was exposed to photolytic conditions (1.25 million lux hours of fluorescent light and $200 \mathrm{Whm}^{-2}$ of UV light).

\section{Thermal degradation}

The drug HCTZ was found to be stable on exposure to dry heat at $70{ }^{\circ} \mathrm{C}$ for a period of 3 days.

Validation of developed stability indicating method

\section{Specificity}

The mixture of degradants was analyzed using developed HPLC method. The method was found to be specific, selective and stability indicating as the peaks of degradants were found to be well-resolved from the drug and from one another. The chromatogram is depicted in Figure 2. The resolution amongst the peaks was found to be $>2$. The peak purity of HCTZ and degradants was recorded using DAD (Table 1) and found to be $>0.999$.

\section{Linearity}

The response for the drug was strictly linear in the investigated concentration range of $10-80 \mu \mathrm{g} \mathrm{mL}^{-1}$ $\left(r^{2}=0.99989\right)$. The equation of line is $y=27754 x+59445$.

\section{Precision}

The intra-day and inter-day precision was determined at three different concentrations $\left(20,40\right.$ and $\left.60 \mu \mathrm{g} \mathrm{mL}^{-1}\right)$ in the linearity range. The data is represented in Table 2 . The 
Table 1. Peak purity data

\begin{tabular}{lccc}
\hline Peak & Retention time / $\left(\mathrm{t}_{\mathrm{R}}\right)$ & Relative retention time / (RRT) $^{\mathrm{a}}$ & Peak purity $(>0.999)$ \\
\hline Deg. A & 9.46 & 0.73 & 0.99983 \\
Deg. B & 10.97 & 0.85 & 1.00120 \\
HCTZ & 12.93 & 1.00 & 0.99935 \\
\hline
\end{tabular}

${ }^{\mathrm{a} R R T}$ is calculated with respect to HCTZ.

$\%$ RSD values for intra-day and inter-day precision were found to be $<2 \%$, indicating that the method was precise.

Table 2. Data of intra-day and inter-day precision studies

\begin{tabular}{lcc}
\hline $\begin{array}{l}\text { Actual } \\
\text { concentration / } \\
\left(\mu \mathrm{g} \mathrm{mL} \mathrm{mL}^{-1}\right)\end{array}$ & $\begin{array}{c}\text { Intra-day measured } \\
\text { concentration } /\left(\mu \mathrm{g} \mathrm{mL} \mathrm{mL}^{-1}\right) \\
\text { Mean } \pm \text { R.S.D. }\end{array}$ & $\begin{array}{c}\text { Inter-day measured } \\
\text { concentration } /\left(\mu \mathrm{g} \mathrm{mL} \mathrm{mL}^{-1}\right) \\
\text { Mean } \pm \text { R.S.D. }\end{array}$ \\
\hline 20 & $20.37 \pm 0.786$ & $20.22 \pm 1.769$ \\
40 & $40.43 \pm 1.627$ & $39.47 \pm 1.898$ \\
60 & $61.63 \pm 0.657$ & $60.76 \pm 0.645$ \\
\hline
\end{tabular}

\section{Accuracy}

Accuracy of the method was determined by conducting recovery studies of pure drug from degradation samples by standard addition method. Good recoveries were obtained when a mixture of stressed samples was spiked with the drug at three given concentration levels with mean recovery being $98.6 \%$. The data is shown in Table 3 .

\section{LC-MS/MS studies on forced decomposition samples of HCTZ}

The developed stability indicating assay method was used as such for LC-MS/MS, as it was compatible with
Table 3. Recovery data for HCTZ

\begin{tabular}{lcc}
\hline $\begin{array}{l}\text { Spiked } \\
\text { concentration / } \\
\left(\mu \mathrm{gL}^{-1}\right)\end{array}$ & $\begin{array}{c}\text { Calculated spiked } \\
\text { concentration / } \\
\left(\mu \mathrm{mL} \mathrm{m}^{-1}\right)\end{array}$ & Recovery / $(\%)$ \\
\hline 20 & $\begin{array}{l}\text { Mean } \pm \text { R.S.D. } \\
19.73 \pm 1.035\end{array}$ \\
40 & $39.22 \pm 1.809$ & 98.64 \\
60 & $59.47 \pm 1.021$ & 98.04 \\
\hline
\end{tabular}

LC-MS/MS. Mass spectra of HCTZ and its degradants were recorded in positive as well as negative mode of electrospray ionization (ESI). The output of the mass spectrometer was validated by injecting standard drug solution of HCTZ. The obtained $\mathrm{m} / z$ values $319.9[\mathrm{M}+\mathrm{Na}]^{+}$ and $296[\mathrm{M}-\mathrm{H}]^{-}$in +ESI and -ESI mode respectively were found to be matching with molecular weight data of HCTZ. The fragmentation pattern of HCTZ was determined by carrying out LC-MS/MS study. The LC-MS/MS data is summarized in Table 4. Mechanistic approach of fragmentation of HCTZ is given in Figure 3.

LC-MS/MS spectra in both ionization modes were recorded for degradants generated under different stress conditions like hydrolysis under acid, alkali and neutral

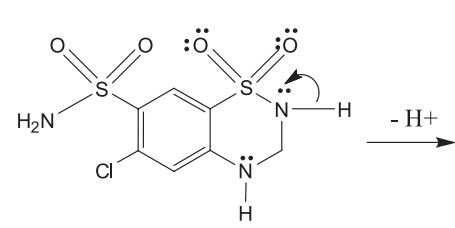

HCTZ

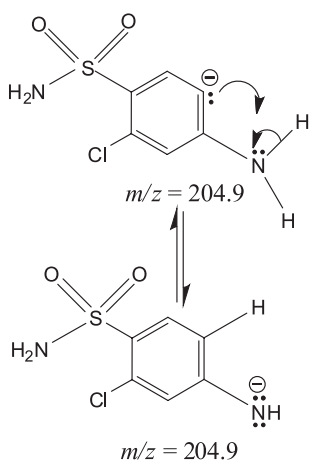<smiles></smiles>

$m / z=296.0$<smiles>Nc1cc(Cl)c(S(N)(=O)=O)c(S(=O)(=O)[O-])c1</smiles>

$m / z=268.9$

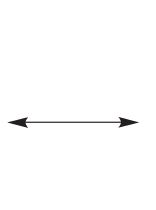

<smiles>CNc1cc(Cl)c(S(N)(=O)=O)cc1S(=O)(=O)NC</smiles>

$\mathrm{H}$

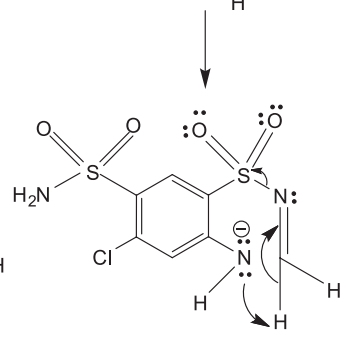

Figure 3. Fragmentation pathway of HCTZ in negative ionization mode. 
Table 4. Summary of LC-MS/MS results for HCTZ and its degradants

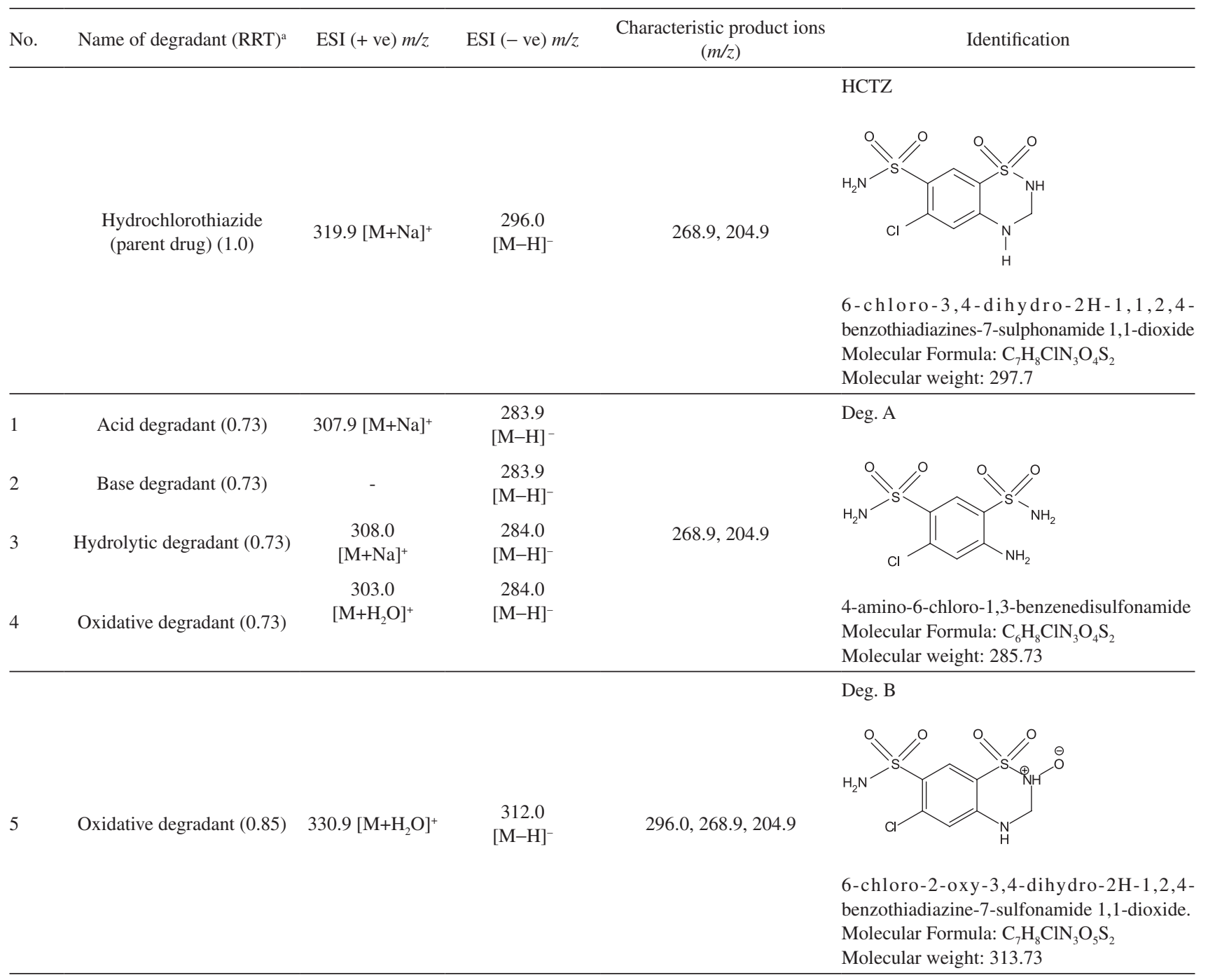

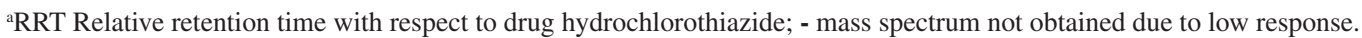

conditions and also oxidative stress. The summary of LC-MS/MS results along with structures of degradants is given in Table 4. Mechanistic approach towards hydrolytic degradation of hydrochlorothiazide is given in Figure 4. The results of LC-MS/MS showed that degradation product (Deg. A) formed after hydrolysis had molecular mass of 284 Da which is compound VII (Figure 4). It was formed by loss of formaldehyde after hydrolysis. ${ }^{15}$ This happened by initial ring opening to give compound III (Figure 4) which is stabilized by resonance (III, III A, III B). Water molecule then attacks compound III by 1,4 addition across the double bond, finally leading to loss of formaldehyde (Figure 4). The degradant (Deg. A) was identified as 4-amino-6chlorobenzene-1,3-disulphonamide (ACD), which is one of the process related impurities mentioned in the official monographs. Deg. B was identified as 6-chloro-2-oxy3,4-dihydro-2H-1,2,4-benzothiadiazine-7-sulfonamide1,1- dioxide from its mass spectral data. It has molecular weight 313 Da which is exactly 16 Da greater than HCTZ.

\section{Assay of HCTZ tablets}

The proposed method was applied for the determination of HCTZ in tablet dosage form. Twenty tablets were powdered and three samples were analyzed. The result of the assay yielded $99.58 \pm 0.36 \%(\% \mathrm{RSD}=0.36)$ of label claim of the tablet. The results of the assay (Table 5) indicate that the method is selective for the assay of HCTZ without interference from the excipients used in these tablets.

\section{Conclusions}

The proposed stability indicating HPLC method was developed on C18 column. The method was validated for 
<smiles>CCNN1CN(CC)S(=O)(=O)c2cc(S(N)(=O)=O)c(Cl)cc21</smiles><smiles>CN([18OH])c1cc(Cl)c(S(N)(=O)=O)cc1S(=O)(=O)N(C)C</smiles><smiles>CCN1CNc2c1cc(S(N)(=O)=O)c(Cl)c2I</smiles><smiles>Nc1cc(S(N)(=O)=O)c(S(N)(=O)=O)cc1Cl</smiles><smiles>NS(=O)(=O)c1cc(S(N)(=O)=O)c(N[18OH])cc1Cl</smiles>

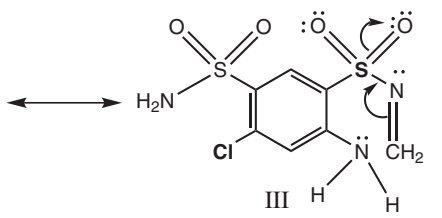

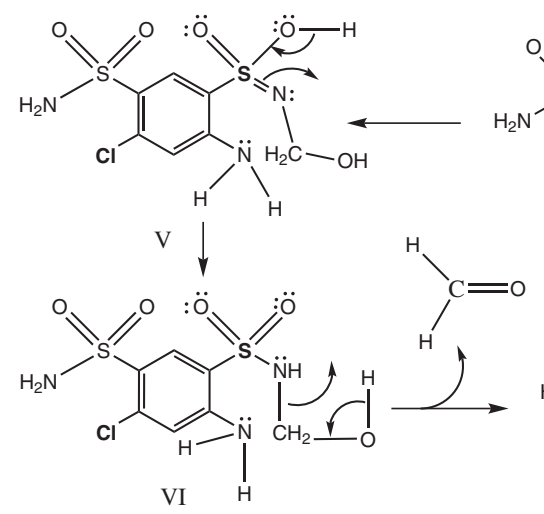<smiles>CCN(CCO)c1cc(Cl)c(S(N)(=O)=O)cc1N(C)C</smiles><smiles>NC(NCCOP)Nc1cc(S(N)(=O)=O)c(S(N)(=O)=O)cc1Cl</smiles>
III<smiles>Nc1cc(Cl)c(S(N)(=O)=O)cc1S(N)(=O)=O</smiles>

VII

Figure 4. Mechanistic approach towards degradation of HCTZ by hydrolysis.

Table 5. Results of analysis of tablet formulation

\begin{tabular}{lccc}
\hline Tablet formulation & Label claim / (mg per tablet) & Amount of drug estimated & \% of label claim Mean \pm R.S.D. \\
\hline Aquazide & 12.50 & 12.39 & $99.12 \pm 0.36$ \\
\hline
\end{tabular}

Number of tablets $=20, \mathrm{n}=3$.

specificity, linearity, accuracy and precision. It was capable of separating HCTZ from its two degradation products. This demonstrates its suitability for use as a stability indicating method during stability studies.

Data obtained through LC-MS/MS studies and $\mathrm{m} / \mathrm{z}$ values of degradants helped to propose the structures of degradants along with degradation route of drug. This information is being reported for the first time.

Furthermore the developed method showed no interference of the formulation excipients and was successfully applied for determination of HCTZ in pharmaceutical formulation.

\section{Acknowledgments}

The authors wish to thank IPCA laboratories, Ratlam, India for gift sample of HCTZ and DBT-ICT Center for Energy Biosciences, Mumbai for conducting LC-MS/MS studies.

\section{References}

1. Bakshi, M.; Singh, S.; J. Pharm. Biomed. Anal. 2002, 28, 1011.

2. International Conference on Harmonization; Guideline on Stability Testing of New Drug Substances and Products, Q1A (R2), 2003.

3. International Conference on Harmonization; Guideline on Impurities in New Drug Products, Q3B (R2), 2006.

4. International Conference on Harmonization; Guideline on Specifications: Test Procedures and Acceptance Criteria for New Drug Substances and New Drug Products: Chemical Substances, Q6A, 1999.

5. US Food and Drug Administration; Code of Federal Regulations, Current Good Manufacturing Practice for Finished Pharmaceuticals, 21CFR211, 2008.

6. Bakshi, M.; Singh, S.; Pharm. Technol. On-Line, 2000 (available under request).

7. Sweetman, S. C.; Martindale, the Complete Drug Reference, $35^{\text {th }}$ ed.; Pharmaceutical Press: United Kingdome, UK, 2007. 
8. Carter, B. L.; Ernst, M. E.; Cohen, J. D.; Hypertension 2004 $43,4$.

9. The United States Pharmacopeia 32, National Formulary 27; United States Pharmacopoeial Convention: Rockville, 2009.

10. The European Pharmacopeia, $6^{\text {th }}$ ed.; Directorate of the Quality of Medicines and Health Care of the Council of Europe, 2008.

11. Vetuschi, C.; Giannandrea, A.; Carlucci, G.; Mazzeo, P.; Farmaco 2005, 60, 665.

12. Liu, F.; Yux, U.; Gao, S.; Zhung, J.; Guo, Q; J. Pharm. Biomed. Anal. 2007, 44, 1187.

13. Maggio, R. M.; Castellano, P. M.; Kaufman, T. S.; Anal. Bioanal. Chem. 2008, 391.

14. Kartal, M.; Erk, N.; J. Pharm. Biomed. Anal. 1999, 19, 477.

15. Mollica, J. A.; Rehm, C. R.; Smith, J. B.; J. Pharm. Sci. 1969, 58,635 .

16. Swasono, R.; Tamat, E.; J. Pharm. Sci. 1983, 72, 180.
17. Daniels, S. L.; Vanderwielen, A. J.; J. Pharm. Sci. 1981, 70, 211.

18. Tagliari, M. P.; Stulzer, H. K.; Murakami, F. S.; Kuminek, G.; Valente, B.; Oliveira, P. R.; Segatto Silva, M. A.; Chromatographia 2008, 67, 647.

19. Hertzog, D. L.; McCafferty, J. F.; Fang, X.; Tyrrell, R. J.; Reed, R. A.; J. Pharm. Biomed. Anal. 2002, 30, 747.

20. Lusiana, M.; Cindric, T.; Tomaic, J.; Peko, M.; Pozaic, L.; Musulin, N.; Int. J. Pharm. 2005, 291,127.

21. Belal, F.; Al-Zaagi, I. A.; Gadkariem, E. A.; Abounassif, M. A.; J. Pharm. Biomed. Anal. 2001, 24, 335.

22. International Conference on Harmonization; Validation of Analytical Procedures: Text and Methodology, Q2 (R1), 1995.

Submitted: July 21, 2011

Published online: January 10, 2012 